\title{
Evaluation of real time PCR technique to diagnosis of human T-lymphotropic virus type I (HTLV-I) in patients in the Hematologia da Fundação Hemope Hospital, in Northeastern Brazil

\author{
Avaliação da técnica de PCR em tempo real para o diagnóstico do virus linfotrópico tipo I de \\ células T humana (HTLV-I) em pacientes do Hospital de Hematologia da Fundação Hemope, no \\ Nordeste do Brasil
}

\author{
Bruna C. Arrudal \\ Rodrigo A. Lira ${ }^{2}$ \\ Paula Loureiro ${ }^{3}$ \\ Lucas Brandão ${ }^{4}$ \\ Paulo Souza ${ }^{5}$ \\ Wayner V. Souza ${ }^{6}$ \\ Yara M. Gomes ${ }^{7}$
}

\begin{abstract}
As a high degree of homology exists between the proviral genomes of HTLV-I and HTLV-II, there is significant cross-reactivity. Therefore although detection of HTLV antibodies is characteristic of viral infection, it is not sufficient to confirm the presence of the viral type. Molecular tests used to diagnose the HTLV-I/II viruses are based on investigations of proviral genomic sequences, and allow for an infection to be diagnosed prior to the appearance of any sign or symptom. The HTLV proviral load in infected individuals can be determined using real-time PCR, a faster method with less risk of contamination than simple or nested PCR. We analyzed 63 samples from the Hemope Hospital, of which 33 were from HTLV seropositive individuals and 30 from blood donors, to determine the type of virus and the proviral load. The sensitivity of qualitative PCR in comparison to ELISA was $87.5 \%$ (95\% IC: 70.1 - 95.9\%) and the specificity was 100\% (IC 95\%: 85.9 - 100.0\%). The sensitivity and specificity of real-time PCR in comparison to the serological test (ELISA) were 100\% (95\% IC: $86.7-100.0 \%)$ and 96.67\% (95\% IC: 80.9 - 99.8\%) respectively. The proviral load in the seropositive individuals ranged from 13 to 343820 copies/106 PBMC cells. Our study also observed that individuals with TSP/HAM had a higher proviral load than those who showed no symptoms. The use of real time PCR for routine clinical testing of infected individuals will play a significant role in identifying the virus type and determining the proviral load, thereby providing more appropriate treatment. Rev. Bras. Hematol. Hemoter. 2008;30(5):384-389.
\end{abstract}

Key words: Human T-cell lymphotropic virus; HTLV-I infections; molecular diagnosis; polymerase chain reaction.

\footnotetext{
${ }^{I}$ Farmacêutica Bioquimica do setor de Biologia Molecular do Doador da Fundação Hemope - Recife-PE.

${ }^{2}$ Bolsista da CPqAM/Fiocruz-PE

${ }^{3}$ Médica da Fundação Hemope.

${ }^{4}$ Bolsista do Lika/UFPE-PE.

${ }^{5}$ Prof. Adjunto da Universidade de Pernambuco (UFPE) - Recife-PE.

${ }^{6}$ Vice-Diretor de Ensino do CPqAM/Fiocruz-PE.

${ }^{7}$ Vice-Diretora de Pesquisa e Desenvolvimento Tecnológico-CPqAM/Fiocruz-PE.

Centro de Pesquisas Aggeu Magalhães (Fiocruz), Fundação de Hematologia e Hemoterapia de Pernambuco (Hemope),

Laboratório de Imunopatologia Keizo Assami-LIKA/UFPE
}

Correspondência: Yara M. Gomes

Departamento de Imunologia, Centro de Pesquisas Aggeu Magalhães - CPqAM/Fiocruz

Av. Prof. Moraes Rego s $/$, Cidade Universitária

50670-420 - Recife-PE - Brazil

Phone: 5581 2101-2559; Fax: 558134532449

E-mail:yara@cpqam.fiocruz.br 


\section{Introduction}

Screening tests for HTLV-I and II were first introduced at blood centers in Japan in 1986, in the United States in 1988, and in Brazil only in 1993. The purpose of this was to prevent the transmission of these agents during hemotherapy. Since then a significant number of asymptomatic carriers of these viruses have been identified. ${ }^{1}$ According to Catalan-Soares et al. ${ }^{2}$ in Brazil, the mean prevalence rate of infection varies considerably; from 0.4/1000 donations in the State of Santa Catarina, to 7.5/1000 donations in the State of Pernambuco and 10/1000 donations in the State of Maranhão (the highest incidence recorded). This differs from the figures found in other countries, such as Canada, where the incidence of positive results is $0.48 / 100000$ individuals/year.3 Laboratory diagnosis of HTLV-I and HTLV-II infection may be required in a variety of clinical situations: i) when a patient exhibits symptoms of the illnesses caused by these retroviruses to corroborate the hypothesis of the clinical diagnosis; ii) during diagnostic screening of individuals who have been exposed to HTLV-I or HTLV-II, such as, for example, the sexual partners of asymptomatic carriers and family members; iii) as part of the compulsory screening for bone marrow and blood donors. ${ }^{1}$

Diagnosis of HTLV-I/II infection is usually carried out using serological tests based on antibodies generated to combat virus antigens in the serum of infected individuals. Several tests for the serological diagnosis of HTLV infection are currently available on the market, and include: i) latex particle or gelatin tests; ii) ELISA - Enzyme-Linked Immunosorbent Assay; iii) RIPA-Radioimmunoprecipitation; iv) IIF-Indirect immunofluorescence and v) Western Blot. The last two are normally used as tests to confirm a previous diagnosis.

Due to the high degree of homology between the two types of HTLV, although the detection of anti-HTLV-I/II antibodies using conventional serological tests is characteristic of cases of viral infection, it is not sufficient to distinguish between type I and type II. The discriminatory serological tests are themselves based on research into antibodies produced to combat specific epitopes of each HTLV type. For this reason, immunonenzymatic assays, which contain synthetic peptides which are type-specific antigens, ${ }^{4}$ or Western blot modified assays, which incorporate recombinant antigens which are type-specific to viral lysate, ${ }^{5}$ are used. However, it should be remarked that, in some cases, even the discriminatory serological tests are not always capable of identifying the type of HTLV responsible for the infection, which makes it more difficult to provide individuals with the appropriate medical advice. ${ }^{1,6}$

Furthermore, two new types of HTLV have recently been discovered: HTLV-3 and HTLV-4. When analyzed using the confirmatory serological assays currently available, they gave HTLV-I indeterminate or false-positive or HTLV-II falsepositive results. ${ }^{7,8}$
The molecular assays used for diagnosis of HTLV-I/II infection are based on research into the gene sequences of lysates of mononuclear peripheral blood cells. Unlike other retroviruses, the viral load circulating in the blood of HTLVinfected individuals is very small. Therefore, its detection by molecular assays is carried out using DNA as the target nucleic acid. Conserved regions of the viral genome (pol or tax) have normally been used for this, along with consensual primers, which are capable of amplifying both sequences of HTLV-I and HTLV-II. The HTLV proviral load in infected individuals can be determined using real time PCR, which is a quicker technique and less prone to contamination than simple or nested PCR, since amplification and measurement can be carried out in a single closed reaction tube. ${ }^{9}$ Furthermore, this allows detection to be visualized during amplification, and is used to determine the HTLV proviral load, due to its speed, precision and accuracy.

In this study, we evaluated the performance of real time PCR in the diagnosis of the HTLV-I, with a view to its routine use in the laboratory of the Hematologia da Fundação de Hematologia e Hemoterapia de Pernambuco Hospital, in Brazil (Hemope Hospital).

\section{Methodology}

\section{Study population}

The population was a convenient non-probabilistic sample, selected between November 2006 and April 2007, made up of individuals whose serum tested positive for antiHTLV antibodies $(n=33)$, attending an outpatients clinic at Hemope Hospital, in Recife, the capital of the State of Pernambuco, in the Northeast of Brazil, as well as a similar number of blood donors $(\mathrm{n}=30)$ from the same institution. After standard clinical-laboratory tests had been carried out, individuals whose serum tested positive using ELISA (Murex Biotech Limited, UK), were selected to perform qualitative PCR. Blood donors who tested negative for the virus were used as a control. The study was approved by the Research Ethics Committee of Hemope Hospital and by the Research Ethics Committee of the Aggeu Magalhães Research Center/ Fiocruz. The patients were evaluated by the doctor responsible for the Hematology Unit of Hemope Hospital, with the assistance of a psychologist, a specialist in medical genetics and a social worker. Those who tested positively for HTLV were referred for counseling.

\section{Obtaining the PBMC}

The blood, collected in a tube containing EDTA, was first centrifuged at $300 \mathrm{x}$ g for 7 minutes and the plasma removed. The remaining blood was diluted in an equal quantity of $0.01 \mathrm{M}$ PBS, pH 7.2 (1:1). Five $\mathrm{mL}$ of the blood diluted in PBS was carefully put in a $15 \mathrm{~mL}$ tube containing $2 \mathrm{~mL}$ of Ficoll (Amersham Pharmacia Biotehc, Uppsala, Sweden). The tube was centrifuged for $30 \mathrm{~min}$ at $800 \mathrm{xg}$, the 
leucocytary ring formed immediately, and was collected and transferred to another $15 \mathrm{mLltube}$, where it was washed twice in PBS, being centrifuged for 5 minutes at $300 \mathrm{x}$ g between washings. The cells were re-suspended in 1 to $3 \mathrm{ml}$ of PBS and counted in a Neubauer chamber. Tubes containing $10^{6}$ cells were separated, centrifuged and the pellet-stored at $-20^{\circ} \mathrm{C}$.

\section{Extraction of the DNA from PBMC cells}

The extraction of DNA was carried out using the "DNA Purification and Extraction GFX Column" kit (Amersham Pharmacia Biotehc, Uppsala, Sweden), in accordance with the manufacturer's instructions.

\section{Qualitative Nested PCR}

The DNA was submitted to qualitative PCR carried out using a 2-phase amplification. For the first amplification of HTLV-I, the following primers were used: SK110-pol: 5 - CCC TAC AAT CCAACC AGC TCA G - 3 and SK44-tax: 5 - GAG CCG ATA ACG CGT CCA TCG - 3. For the second amplification the primers were: SK248-env: 5 - CAT GTC GAC GCT CCA GGA TAT GAC C - 3 and SK249-env: 5 - CAGACC GCC ACC GGT ACC GCT CGG C - 3. The primers were obtained by GenBank (access J02029). The amplification reaction mixture for HTLV-I, with a final volume of $20 \mathrm{~mL}$ contained $20 \mu \mathrm{M}$ Tris-HCL (pH 8.4), $50 \mathrm{mM} \mathrm{KCl}, 1.25 \mathrm{mM}$ $\mathrm{MgCl}_{2}, 5$ pmol of each primer, $0.2 \mathrm{mM}$ DNTP (final concentration of $200 \mu$ ols for each dnucleotide), $0.5 \mathrm{U}$ of Taq DNA Polimerase and $2 \mu \mathrm{L}$ of the extracted DNA. The first amplification was performed at $95^{\circ} \mathrm{C}$ for $7 \mathrm{~min}, 35$ cycles of $55^{\circ} \mathrm{C}$ for $1.5 \mathrm{~min}, 72^{\circ} \mathrm{C}$ for $2 \mathrm{~min}$ and $95^{\circ} \mathrm{C}$ for $1 \mathrm{~min}$, and finally an additional $10 \mathrm{~min}$ at $72^{\circ} \mathrm{C}$. For the second amplification the same reaction mixture was used, changing only the primers used and the product of the first amplification diluted at 1:100 as a template. The amplification protocol involved denaturation at $94^{\circ} \mathrm{C}$ for $5 \mathrm{~min}, 30$ cycles at $58^{\circ} \mathrm{C}$ for $1 \mathrm{~min}$, $72^{\circ} \mathrm{C}$ for $2 \mathrm{~min}$ and $94^{\circ} \mathrm{C}$ for $1 \mathrm{~min}$, followed by an extension at $72^{\circ} \mathrm{C}$ for $10 \min ^{10}$ (modified). The final result was a $466 \mathrm{bp}$ product.

In the case of the HTLV-II, the first amplification used the following primers: ET401-env/tax: 5 - CTC CAT TTC TGG GAA CAA GGG GGT TT - 3 SK44. The second amplification used ET403 env/tax: 5 - GGC TGG GGA CTA AAC TGG GAT CCT GG - 3 and ET404 env/tax: 5 - CCA AAC ACG TAG ACG GGG GAT CC - 3. The primers were obtained by GenBank (access NC001488). The amplification reaction mixture for the HTLV-II, also with a final volume of $20 \mu \mathrm{L}$, contained $20 \mathrm{mM}$ Tris-HCL (pH 8.4), $50 \mathrm{mM} \mathrm{KCl}, 3.0$ $\mathrm{mM} \mathrm{MgCl}, 5$ pmol of each primer, $0.2 \mathrm{mM}$ DNTP (final concentration of $200 \mu \mathrm{ols}$ for each dnucleotide), $0.2 \mathrm{mM}$ DMSO (Merck, Darmstadt, Germany), 0.5 U of Taq DNA Polimerase and $2 \mathrm{~mL}$ of the extracted DNA as a template. The first and second amplifications followed the same cycling protocol as the first amplification for HTLV-I. The second amplification used the same reaction mixture changing only the primers and using the product of the first amplification diluted at 1:100 as a template ${ }^{10}$ (modified). The final result was an 821 bp product.

\section{Real time PCR}

The plasmid used to plot the standard curve was provided by the LASP - Laboratório Avançado de Saúde Pública of the Centro de Pesquisas Gonçalo Moniz in Bahia, Brazil. It is a clone with double insertion containing a portion of the intron 12 of the albumin gene and the pol region of the HTLV-I genome, lying between positions 4708 and 4953. ${ }^{11}$ The fluorescence dye chosen was the Sybr Green (Applied Biosystem/Foster City, U.S.A.).

\section{Measurement of HTLV-I in the samples}

All the samples were amplified in duplicate using the following primers: SK 110: 5' - CCC TAC AAT CCAACCAGC TCAG-3' and SK 111:5'-GTGGTGAAGCTGCCATCGGGT TTT $-3{ }^{\prime} .{ }^{11}$ For the HTLV-I and albumin, the following amplification protocol was used: $2 \mathrm{~min}$ at $50^{\circ} \mathrm{C}, 10 \mathrm{~min}$ at $95^{\circ} \mathrm{C}$, 45 cycles of $15 \mathrm{sec}$ at $95^{\circ} \mathrm{C}$ and $1 \mathrm{~min}$ at $65^{\circ} \mathrm{C}$ and were amplified in parallel in the Rotor Gene 3000 (Corbett Life Science, Sydney, Australia).

\section{Measurement of the albumin in the samples}

All the samples were amplified in duplicate using the following primers: Alb-S: 5'-GCT GTC ATC TCT TGT GGG CTG T - ${ }^{\prime}$ ' and Alb-The: 5' - AAA CTC ATG GGA GCT GCT GGT $\mathrm{T}-3^{\prime} \cdot{ }^{11}$ The main mixture used in the two reactions utilized $2 \mathrm{~mL}$ of the DNA, $10 \mu \mathrm{L}$ of each first and Green Master Mix, to a total of $25 \mathrm{~mL}$ of reaction. The HTLV-I proviral load was calculated as the ratio between the mean number of copies of HTLV-I and the mean number of copies of albumin $\times 2 \times 10^{6}$ and expressed as the number of copies/ 106 PBMC cells. ${ }^{11}$

\section{Data analysis}

The real time PCR DNA detection limit for the quantification of the HTLV-I proviral load was analyzed by means of serial dilutions $\left(10^{0}\right.$ to $\left.10^{5}\right)$. Win Episcope 2.0 software $^{12}$ was used to calculate the values for the sensitivity and specificity of the tests. The confidence interval (CI) was established at $95 \%$.

\section{Results}

Sixty-three samples were analyzed: 33 samples tested serologically positive for HTLV and 30 samples tested negative. The positive group contained 27 women with a mean age of 47 years, and 6 men with a mean age of 48 years. The group of individuals testing negative (the Control Group) comprised 26 men with a mean age of 35 years and 4 women with a mean age of 35 years. 


\section{Qualitative PCR for HTLV-I and II}

The results of the analysis of the qualitative HTLV PCR are shown in Figure 1 and Table 1. All of the individuals who tested serologically negative were also negative in the qualitative PCR and only one was HTLV-II positive. The group of individuals testing positive presented 4 negative results using qualitative PCR. The sensitivity of qualitative PCR was $87.9 \%$ (95\% CI: $70.1-95.0 \%)$ and the specificity $100 \%(95 \%$ CI: 85.9-100.0\%).

\section{6}

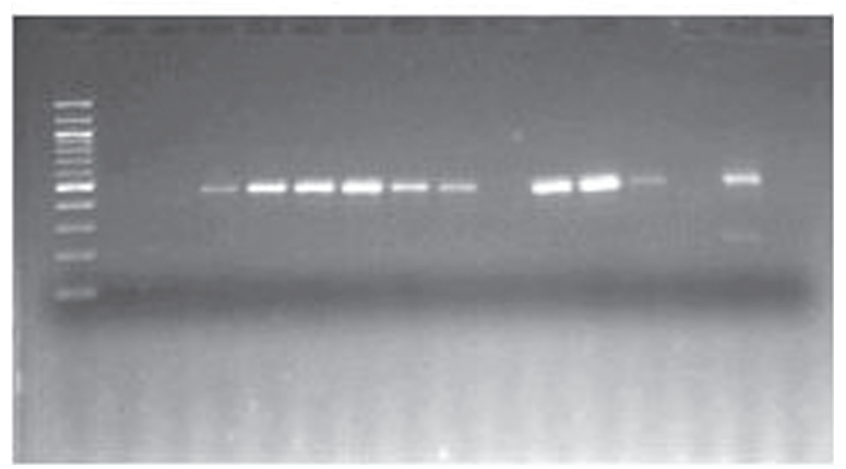

Figure 1. Representative sample of qualitative PCR for HTLV-I. Line 1 - standard molecular weight of $100 \mathrm{pb}$, lines 2, 3, 10 and 14 - samples testing negative. Lines 4 to 9,12 to 13 - samples testing positive, line 15 - control testing positive and line 16 - control testing negative

Table 1. Results of Qualitative PCR for HTLV

\begin{tabular}{lcc}
\hline & HTLV Serological & Reaction Test Result \\
\hline Qualitative PCR & Positive & Negative \\
Positive & 29 & 0 \\
Negative & 4 & 30 \\
\hline
\end{tabular}

\section{The HTLV-I Proviral Load}

Once the standard curve had been calculated, the software automatically quantified the number of DNA of HTLV-I or of albumin, reporting the Ct of the sample to the $\mathrm{Ct}$ of the standard curve (Figures 2 and 3). The HTLV-I proviral load was then calculated using the following formula: (mean number of HTLV-I copies / mean number of albumin copies) $\times 2 \times 10^{6}$. The results were expressed as the number of copies $/ 10^{6} \mathrm{PBMC}$ cells. The proviral load of the individuals testing serologically positive, as measured using real-time PCR, ranged between 13 copies $/ 10^{6} \mathrm{PBMC}$ cells and 343,820 copies $/ 10^{6} \mathrm{PBMC}$ cells (Figure 4). Of the 30 individuals who tested negative, one showed a proviral load of 308 copies $/ 10^{6}$. The sensitivity and specificity of realtime PCR were $100 \%$ (95\% CI: $86.7-100.0 \%$ ) and $96.67 \%$ (95\% CI: 80.9 - 99.8\%), respectively. Based on the analysis of the CI, the qualitative PCR and the real-time PCR tests did not show significantly different sensitivities and specificities.

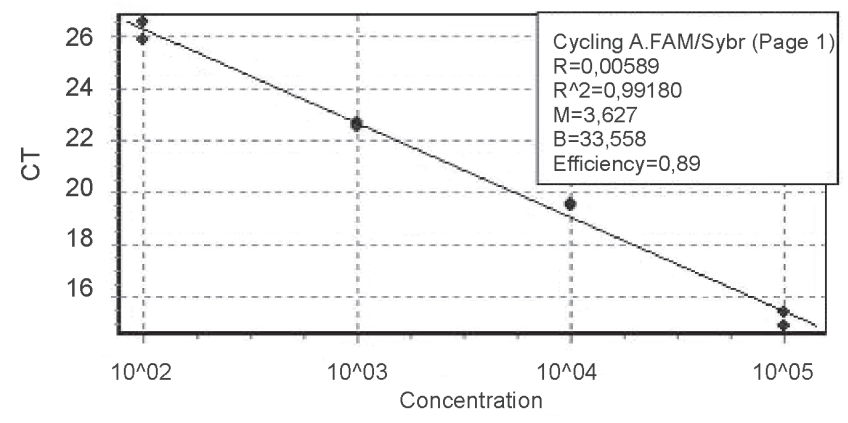

Figure 2. Linear regression of standard HTLV-I curve

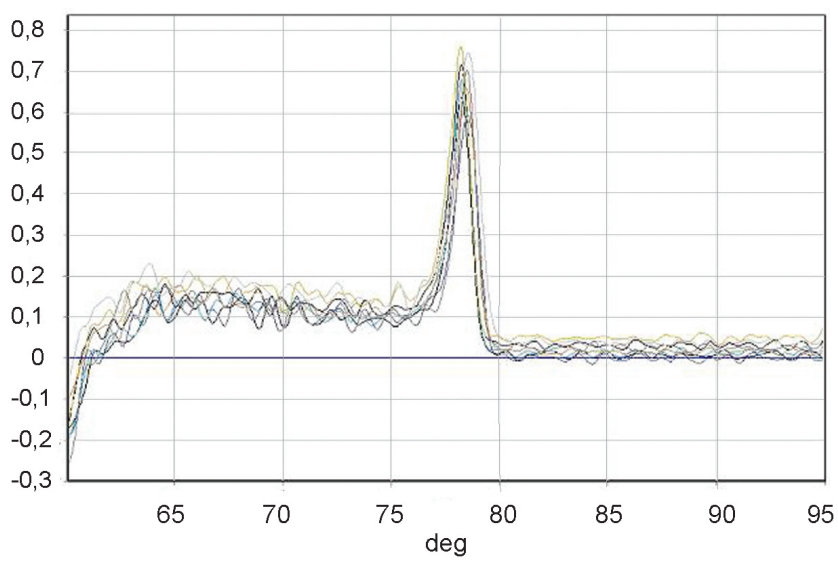

Figure 3. Curve showing deviation from HTLV-I standards

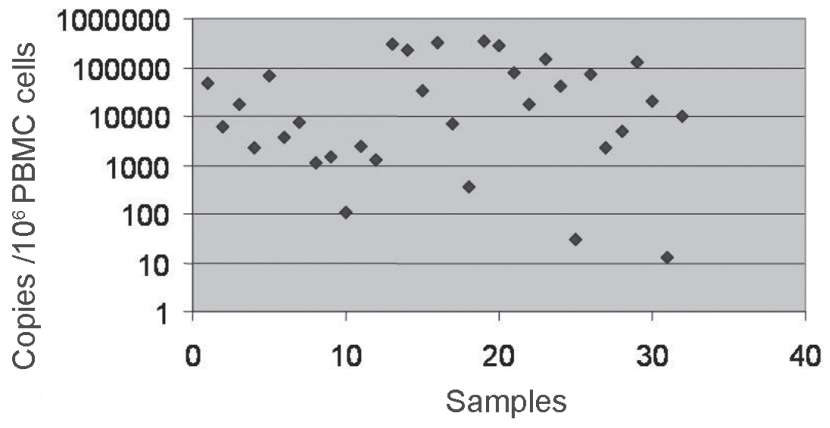

Figure 4. Proviral load dispersion by real time PCR from HTLV-I positive patients

\section{Discussion}

Laboratory screening/diagnosis of HTLV infection is carried out using serological assays, principally ELISA, with the Western blot being used to confirm the diagnosis and to determine the type of the virus (I or II). In cases where Western blot proves inconclusive, molecular approaches should be used $^{8,13,14}$ which show, especially when PCR is used, a higher degree of specificity. ${ }^{15}$ Real-time PCR allows the detection and quantification of target sequences by continuously measuring the fluctuations in fluorescence during reaction 
amplification. This is carried out in a closed system, thereby diminishing the risk of contamination and eliminating the gel phase of standard PCR. ${ }^{16}$ During real-time PCR, or, more precisely, during the annealing phase of the primers and the extension of the target sequence, larger quantities of SYBR Green are linked to the double strands of DNA, which leads to an increase in the emission of fluorescence. When the DNA is once again denaturized during the PCR cycle, the SYBR Green detaches itself, thereby diminishing the emission of fluorescence. ${ }^{17}$

According to Gunson et al. ${ }^{16}$ the property of SYBR Green linking itself to double strands of DNA has both advantages and disadvantages. It may produce annealing base errors during the extension phase, but it is, nevertheless, capable of cross-linking itself and emitting fluorescence. This is a highly valuable property when studying viruses, because even small sequence mutations or changes in conserved regions can lead to annealing probe errors, causing falsenegative results. With SYBR Green this possibility still exists, but it is limited when compared to assays that use probes. However, this very same property reduces the specificity of the reaction. Fluorescence emission may occur even when the sample is negative, owing to the connection of the SYBR Green to primer dimmers. ${ }^{16,17}$ To avoid errors in analysis, we used the dissociation curve, which allows amplicon sizes to be distinguished from primer dimers.

The use of SYBR Green in our study was based on the fact that it is a cheaper assay and does not require a specific probe. The primers are used to amplify the pol region of the HTLV-I virus, because this is a conserved region and has already been used in several studies involving viruses..$^{11,18,19}$

The HTLV-I standard curve was plotted using serial dilutions of the plasmid from $10^{0}$ to $10^{5}$. After carrying out real-time PCR with the dilutions in triplicate, the detection limit observed was 10 copies/reaction, where the dilution of $10^{3}$ copies had a Ct of 22.59 , confirming the results obtained by Lee et al. ${ }^{10}$

In the group which tested serologically negative for HTLV-I, i.e. the Control Group, all 30 individuals also showed up negative when qualitative PCR was used. However, one individual exhibited a proviral load of $30^{8}$ copies / $10^{6} \mathrm{PBMC}$ cells when real-time PCR was used. Both the qualitative PCR and real-time PCR tests were repeated and the same results were produced, suggesting a possible cross-over contamination. The results for the proviral load in the individuals who tested serologically positive ranged between 13 and 343,820 copies $/ 10^{6}$ PBMC cells, corroborating the results of other studies. ${ }^{10,20,21}$ Like other studies, ${ }^{19,20,21}$ our study also observed that individuals with PET/MAH had a higher proviral load than those who exhibited no symptoms. However, it remains to be scientifically proven that an inverse relation exists; that HTLV-I carriers with a high proviral load, in whom no clinical illness has been identified, are more susceptible to develop the illnesses associated with the virus.
For this reason, as suggested by Montanheiro et al., ${ }^{19}$ there is a need for a long term follow-up involving asymptomatic carriers.

Although the present study did not show any statistical difference between the two molecular approaches to the identification of the HTLV-I, the occurrence of false-negative results, at almost $10 \%$, was observed in the qualitative PCR results. If this observation is reproduced in a larger sample, real-time PCR could be seriously considered as a means of identifying the virus and simultaneously determining the proviral load.

If it is established that HTLV-I carriers with a high proviral load more frequently develop leukemia and neurological illnesses when compared to those with a low proviral load, this would raise questions regarding the current Ministry of Health guidelines on follow-up procedures and provide them with some degree of uniformity. In this case, a different clinical follow-up strategy should be adopted for asymptomatic carriers, in the expectation that earlier diagnosis and treatment of clinical illnesses may result in a more optimistic prognosis.

\section{Resumo}

Como os genomas provirais do HTLV-I e HTLV-II exibem grande homologia, há uma expressiva sororeatividade cruzada. Assim, a detecção de anticorpos anti-HTLV-I/II embora caracterize infecção viral, não permite estabelecer distinção entre os agentes. Os testes moleculares empregados para o diagnóstico dos vírus HTLV-I/II, baseiam-se na pesquisa de seqüencias genômicas provirais permitindo o diagnóstico da infecção antes de aparecer sinal ou sintoma. A carga proviral de HTLV pode ser determinada através da utilização da PCR em tempo real, uma técnica rápida e com menor risco de contaminação que a PCR simples ou nested PCR. Analisamos, 63 amostras do Hospital HEMOPE, das quais 33 foram de indivíduos com sorologia reagente para HTLV e 30 de doadores de sangue, para determinar o tipo de virus e a carga proviral. A sensibilidade da PCR qualitativa em relação ao ELISA foi de 87,9\% (IC 95\%: 70,9-96,0\%) e a especificidade foi de 100\% (IC 95\%: 85,9-100,0\%). A sensibilidade e especificidade da PCR em tempo real foram de 100\% (IC 95\%: 86,7-100,0\%) e 96,67\% (IC 95\%: 80,9-99,8\%), respectivamente. A carga proviral variou entre 13 cópias $/ 10^{6}$ células PBMC e 343820 cópias $/ 10^{6}$ células PBMC. Nosso estudo também observou que os individuos com PET/MAH tiveram carga proviral mais elevada que a dos indivíduos assintomáticos. A utilização da PCR em tempo real na rotina clínica dos indivíduos infectados poderá desempenhar um papel relevante na identificação do vírus e na determinação da carga proviral, contribuindo para direcionar um tratamento adequado. Rev. Bras. Hematol. Hemoter. 2008; 30(5):384-389.

Palavras-chave: Virus linfotrópico T humano; infecções por HTLV-I; diagnóstico molecular; reação em cadeia da polimerase. 


\section{References}

1. Segurado AAC. Infeccção por HTLV-I e HTLV-II. In: Ferreira AW \& Ávila SLM. Diagnóstico laboratorial das principais doenças infecciosas e parasitárias. Editora Guanabara Koogan, 2a . Edição, p.103-110, Rio de Janeiro, 2001.

2. Catalan-Soares B, Carneiro-Proietti AB, Proietti FA; Interdisciplinary HTLV Research Group. Heterogeneous geographic distribution of human T-cell lymphotropic viruses I and II (HTLV-I/II): serological screening prevalence rates in blood donors from large urban areas in Brazil. Cad Saude Publica. 2005;21(3):926-31.

3. Chiavetta JA, Escobar M, Newman A, He Y, Driezen P, Deeks S, et $a l$. Incidence and estimated rates of residual risk for HIV, hepatitis $\mathrm{C}$, hepatitis B and human T-cell lymphotropic viruses in blood donors in Canada, 1990-2000, 1990-2000. CMAJ. 2003;169 (8):767-73

4. Lal RB, Heneine W, Rudolph DL, Present WB, Hofhienz D, Hartley $\mathrm{TM}$, et al. Synthetic peptide-based immunoassays for distinguishing between human T-cell lymphotropic virus type I and type II infections in seropositive individuals. J Clin Microbiol. 1991; 29 (10):2253-8.

5. Hadlock KG, Lipka JJ, Chow TP, Foung SK, Reyes GR. Cloning and analysis of a recombinant antigen containing an epitope specific for human T-cell lymphotropic virus type II. Blood. 1992; 79(10):2789-96

6. Santos Tde J, Costa CM, Goubau P, Vandamme AM, Desmyter J, Van Doren $\mathrm{S}$, et al. Western blot seroindeterminate individuals for human T-lymphotropic virus I/II (HTLV-I/II) in Fortaleza (Brazil): a serological and molecular diagnostic and epidemiological approach. Braz J Infect Dis. 2003;7(3):202-9.

7. Calattini S, Chevalier SA, Duprez R, Bassot S, Froment A, Mahieux $\mathrm{R}$, Gessain A. Discovery of a new human T-cell lymphotropic virus (HTLV-3) in Central Africa. Retrovirology. 2005;2:30.

8. Switzer WM, Hewlett I, Aaron L, Wolfe ND, Burke DS, Heneine W. Serologic testing for human T-lymphotropic virus-3 and -4 . Transfusion. 2006;46(9):1647-8.

9. Mackay IM, Arden KE, Nitsche A. Real-time PCR in virology. Nucleic Acids Res. 2002;30(6):1292-305.

10. Lee TH, Chafets DM, Busch MP, Murphy EL. Quantitation of HTLV-I and II proviral load using real-time quantitative PCR with SYBR Green chemistry. J Clin Virol. 2004;31(4):275-82.

11. Dehée A, Césaire R, Désiré N, Lézin A, Bourdonné O, Béra $\mathrm{O}$, et al Quantitation of HTLV-I proviral load by a TaqMan real-time PCR assay. J Virol Methods. 2002;102(1-2):37-51.

12. De Blas I, Ortega C, Frankena K, Noordhuizen J, Thrusfield M. Programa de estatística: Win Episcope 2.0. Faculdad de Veterinaria, 2000. Zaragoza, Wageningen University, University of Edinburgh.

13. Ministério da Saúde. Secretaria em Vigilância da Saúde. Programa Nacional de DST Aids. Guia de manejo clínico de HTLV. Brasília, 2003.

14. Morimoto HK, Morimoto AA, Reiche EM, Ueda LT, Matsuo T, Reiche FV, et al. Difficulties in the diagnosis of HTLV-2 infection in HIV/AIDS patients from Brazil: comparative performances of serologic and molecular assays, and detection of HTLV-2b subtype. Rev Inst Med Trop Sao Paulo. 2007;49(4):225-30.

15. Gallego S, Mangano A, Gastaldello R, Sen L, Medeot S. Usefulness of a Nested-polymerase chain reaction for molecular diagnosis of human T-cell lymphotropic virus type I/II. Mem Inst Oswaldo Cruz. 2004;99(4):377-80.

16. Gunson RN, Collins TC, Carman WF. Practical experience of high throughput real time PCR in the routine diagnostic virology setting. J Clin Virol. 2006;35(4):355-67.
17. Watzinger F, Ebner K, Lion T. Detection and monitoring of virus infections by real-time PCR. Mol Aspects Med. 2006;27(23):254-98.

18. Tosswill JH, Taylor GP, Clewley JP, Weber JN. Quantification of proviral DNA load in human T-cell leukaemia virus type I infections. J Virol Methods. 1998;75(1):21-6.

19. Montanheiro PA, Oliveira AC, Posada-Vergara MP, Milagres AC, Tauil C, Marchiori PE, et al. Human T-cell lymphotropic virus type I (HTLV-I) proviral DNA viral load among asymptomatic patients and patients with HTLV-I-associated myelopathy/tropical spastic paraparesis. Braz J Med Biol Res. 2005;38(11):1643-7.

20. Nagai M, Usuku K, Matsumoto W, Kodama D, Takenouchi N, Moritoyo T, et al. Analysis of HTLV-I proviral load in $202 \mathrm{HAM}$ TSP patients and 243 asymptomatic HTLV-I carriers: high proviral load strongly predisposes to HAM/TSP. J Neurovirol. 1998; 4(6):586-93.

21. Osame M, Matsuzaki T, Nakagawa M, Nagai M, Usuku K, Higuchi I, et al. HTLV-I proviral load correlates with progression of motor disability in HAM/TSP: analysis of $239 \mathrm{HAM} / \mathrm{TSP}$ patients including 64 patients followed up for 10 years. J Neurovirol. 2001;7(3):228-34.

Avaliação: Editor e dois revisores externos

Conflito de interesse: não declarado

Recebido: 12/11/2007

Aceito após modificações: 05/10/2008 